\title{
Serum Matrix Metalloproteinase 3 and Tissue Inhibitor Metalloproteinase 1 in Vascular Dementia: A Comparative Study
}

\author{
Mohammed Zain Abdelwadoud Hussein \\ Ain Shams University Hospital, Cairo, Egypt \\ Email: abdelwadoud76@yahoo.com
}

Received 20 July 2015; accepted 29 August 2015; published 1 September 2015

Copyright (C) 2015 by author and Scientific Research Publishing Inc.

This work is licensed under the Creative Commons Attribution International License (CC BY). http://creativecommons.org/licenses/by/4.0/

(c) () Open Access

\begin{abstract}
Aim: To compare serum level of matrix metalloproteinase 3 (MMP3) and tissue inhibitor metalloproteinase 1 (TIMP1) in vascular dementia patients and healthy control subjects. Methods: A case control study was carried out in Ain Shams University hospital, Cairo, Egypt. 32 cases with vascular dementia were collected and classified into 2 subgroups; vascular dementia of multiinfarct type (VDMI) 14 patients, and vascular dementia of subcortical type (VDSC) 18 subjects. 23 cases with normal cognitive functions were collected as control group. Cases were subjected to comprehensive geriatric assessment, neurological examination, neuropsychological testing and brain CT scan. Blood sample was collected to analyze serum level of matrix metalloproteinase 3 (MMP3) and tissue inhibitor metalloproteinase 1 (TIMP1). Results: Mean serum level of TIMP1 (20.85 $\times$ $10^{3}$ picogram $/ \mathrm{ml}$ ) was significantly lower than mean serum level of TIMP1 in control group (27.69 $\times 10^{3}$ picogram $\left./ \mathrm{ml}\right)(p=0.018)$. The same finding was also evident when comparing VDMI subgroup mean serum TIMP1 $\left(18.71 \times 10^{3} \mathrm{pc} / \mathrm{ml}\right)$ to control group $(\mathrm{p}=\mathbf{0 . 0 2 5})$. There was no significant difference between mean serum MMP3 levels in cases group (mean $=67.39 \times 10^{3}$ ) as compared to control group $\left(\right.$ mean $\left.=61.65 \times 10^{3} \mathrm{pc} / \mathrm{ml}\right)(\mathrm{p}=0.519)$. Conclusion: Patients with VD particularly VDMI has lower serum level of TIMP1 as compared to control group.
\end{abstract}

\section{Keywords}

Multiinfarct Dementia, Matrix Metalloproteinase 3, Tissue Inhibitor Me, Talloproteinase 1, Vascular Dementia, Vascular Dementia of Subcortical Type

\section{Introduction}

Vascular dementia is a decline in thinking skills caused by conditions that block or reduce blood flow to the 
brain, depriving brain cells of vital oxygen and nutrients [1].

VD is diagnosed during lifetime in $20 \%$ of demented patients, and considered the second most frequent type of dementia after AD [2].

Estimated prevalence of VD varies from 1.2 to 4.2 percent of individuals over 65 years [3]. Prevalence increased to about 3.6 percent in men and 5.8 percent in women, over the age of 90 years [4]. VD is the sever form of vascular cognitive impairment (VCI) [5] which may result from vascular dementia of subcortical type (VDSC), multi-infarct dementia (VDMI), single infarct (strategic infarct)dementia, hemorrhagic dementia and hypoperfusion dementia [6]. Multiple strokes with loss of cognition occurring close to the time of the infarct are referred as multi-infarct dementia [7]-[9].

Matrix metalloproteinases (MMPs) comprise a heterogeneous group of proteolytic enzymes whose main characteristic is the utilization of a metal ion to polarize a water molecule and perform hydrolytic reactions. The MMPs are a family of zinc-dependent neutral endopeptidases involved in physiological proteolytic degradation of various components of the extracellular matrix and basement membrane. MMPs play important roles in multiple physiological and pathological processes including angiogenesis, tumor invasion and metastasis [10].

MMPs and tissue inhibitor metalloproteinase (TIMPs) are localized in neuritic senile plaques and neurofibrillary tangles in the postmortem brains of patients with $\mathrm{AD}$ and contribute to $\mathrm{AD}$ pathogenesis by the disruption of the blood-brain barrier and promotion of neurodegeneration [11]. In addition studies had reported an association between AD and MMP-2, MMP-9 and TIMP1 [11]. MMP3 was linked with neurodegenerative diseases, afunctional polymorphism in MMP3 in combination with apolipoprotein epsilon4 non-carriers leads to an increased risk of Alzheimer dementia [12] other studies reported MMP3 being involved in Alzheimer's disease pathogenesis [13].

As well as Metalloproteinases were associated with vascular brain lesions as reported an elevation of MMP9 from 24 - 48 hours after stroke whereas MMP2 rises after 7 days during healing phase [14].

Regarding MMP3 studies has demonstrated that serum MMP3 level is significantly increased at acute stage of large artery atherosclerosis as well as small artery occlusion type strokes [15]. In addition An association of MMP 2, MMP9 and MMP3 in brains of patient with white matter lesions from stroke, multiple sclerosis and vascular dementia at autopsy studies was reported [16]-[19].

\section{Materials and Methods}

\subsection{Subjects}

32 cases with suspected vascular dementia were collected from A in Shams university hospital. After obtaining informed consent they were enrolled in the study. All aspects of the study were conducted in compliance with A in Shams university hospital ethical committee regulations. All patients were subjected to comprehensive geriatric assessment, neurological examination, neuropsychological testing and CT scan brain. Blood samples were collected from both cases and 23 controls subjects without cognitive impairment, who were recruited from Ain Shams University hospital outpatient for assessing MMP3 and TIMP1 after obtaining informed consent. Control subjects were all healthy and free from cognitive impairment (no history suggestive of cognitive decline, normal neuropsychologicaltesting). Cases capturing and collection of samples were carried out from February 2011 to July 2012.

\subsection{Diagnosis}

Attendants of geriatric outpatient clinic with cognitive impairment were assessed for history of stroke or focal neurological deficits and suspected cases of vascular dementia were further assessed by full detailed history including symptoms analyses, drug history assessment and full examination including neurological examination and neuropsychological assessment. Brain CT scan was done to confirm radiological evidence of vascular injury. Brain MRI was done for selected patients for subgroup classification whenever CT results are inconclusive. Diagnosis of vascular dementia was carried out according to NINDS-Airen criteria for diagnosing vascular dementia [20]. Subjects contain 2 subclasses; vascular dementia of multi-infarct type (14 case), vascular dementia with subcortical type which includes (cases of multiple lacunes (14 cases), cases with extensive periventricular white matter lesions (4 cases)). Controls were selected after confirming intact cognitive functions by history and examination. 


\subsection{Enzyme Linked Immunosorbent Assay of Serum}

Levels of MMP3 and TIMP1 were measured in serum by enzyme linked immunosorbent assay. $8 \mathrm{ml}$ of blood were collected and allowed to clot at room temperature, then centrifuged at approximately $1000 \times \mathrm{g}$ for $15 \mathrm{mi}-$ nutes. Serum was separated and aliquoted and stored at $-20^{\circ} \mathrm{C}$ for almost 5 months. Samples were diluted by adding $10 \mu \mathrm{l}$ sample into $90 \mu \mathrm{l}$ sample diluents buffer. Human MMP3 and TIMP1 standard solutions were added to precoated 96-well plate respectively then $0.1 \mathrm{ml}$ of sample diluents buffer were added to control wells (zero well) and $0.1 \mathrm{ml}$ of each properly diluted sample was added to each well. The plates were sealed and incubated for 90 minutes. Then after empting the plates content a $0.1 \mathrm{ml}$ of biotinylated anti human MMP3 and TIMP1 respectively were added to into wells and incubated at $37^{\circ} \mathrm{C}$ for 60 minutes then plates were washed 3 times with $0.01 \mathrm{M}$ TBS. Then $\mathrm{ABC}$ working solution were added and incubated at $37^{\circ} \mathrm{C}$ for 30 minutes. Then plates were washed 5 times with $0.01 \mathrm{M}$ TBS. Then TMB color developing agent were added and incubated at $37^{\circ} \mathrm{C}$ in dark for 30 minutes then TMB stop solution was added and then we read the results [21] [22].

The data was collected coded and entered to a personal computer; the data was analyzed with the program statistical package for social science (SPSS) under windows version 7. Qualitative data is presented in form of frequency tables (numbers and percent) while quantitative data is presented in form of mean and range. Chisquare test was used for comparison of categorical data. And student $t$ test was used for comparison of quantitative data.

\section{Results}

A case control study was conducted. 32 cases and 23 controls. Both groups were matched for age (Table $1, \mathrm{p}=$ 0.164 ) and for gender (Table $2, p=0.396$ ). meanwhile cases and controls were matched for received years of

Table 1. Comparison between cases and controls regarding; age, number of education years, serum levels of MMP3, TIMP1 and MMP3/TIMP1 ratio.

\begin{tabular}{cccccccc} 
& \multicolumn{2}{c}{ Cases } & \multicolumn{2}{c}{ Controls } & \multicolumn{2}{c}{ T test } \\
\cline { 2 - 8 } & Range & Mean $\pm \mathrm{SD}^{\ddagger}$ & Range & Mean \pm SD & $\mathrm{t}$ & $\mathrm{p}$-value \\
\hline Age & $60-87$ & $69.3 \pm 7.84$ & $60-86$ & $66.39 \pm 7.39$ & 1.41 & 0.164 \\
Years of education & $3-16$ & $8.6 \pm 3.95$ & $1-9$ & $5.3 \pm 2.87$ & 1.79 & 0.093 \\
MMP3 & $2.5-110$ & $67.39 \pm 31.99$ & $7-110$ & $61.65-32.74$ & 0.650 & 0.519 \\
TIMP1 & $10-41$ & $20.85 \pm 6.71$ & $11-70$ & $27.69 \pm 13.78$ & -2.43 & $0.018^{*}$ \\
MMP3/TIMP1 ratio & $0.11-9.09$ & $3.726 \pm 2.23$ & $0.20 \pm 6.67$ & $2.96 \pm 2.23$ & 1.242 & 0.22 \\
\hline
\end{tabular}

${ }^{*}=$ significant $(\mathrm{p}<0.05) ;{ }^{\dagger}=\times 10^{3}$ picogram $/ \mathrm{ml}$; MMP3 = matrix metalloproteinase 3 ; TIMP1 = tissue inhibitor metalloproteinase 1.

Table 2. Comparison between cases and controls regarding; chronicillneses (diabetes mellitus, hypertension and ischemic heart disease) and gender difference.

\begin{tabular}{|c|c|c|c|c|c|c|c|}
\hline & & \multicolumn{2}{|c|}{ Cases } & \multicolumn{2}{|c|}{ Control } & \multicolumn{2}{|c|}{ Chi-square } \\
\hline & & Number & $\%$ & Number & $\%$ & $\mathrm{X} 2$ & p-value \\
\hline \multirow{2}{*}{$\mathrm{DM}$} & Yes & 13 & 40.63 & 14 & 63.64 & \multirow{2}{*}{2.761} & \multirow{2}{*}{0.097} \\
\hline & No & 19 & 59.38 & 8 & 36.36 & & \\
\hline \multirow{2}{*}{ HTN } & Yes & 14 & 43.75 & 10 & 43.48 & \multirow{2}{*}{0.00} & \multirow{2}{*}{0.984} \\
\hline & No & 18 & 56.25 & 13 & 56.52 & & \\
\hline \multirow{2}{*}{ IHD } & Yes & 9 & 28.13 & 9 & 39.1 & \multirow{2}{*}{.738} & \multirow{2}{*}{0.392} \\
\hline & No & 23 & 71.88 & 14 & 60.9 & & \\
\hline \multirow{2}{*}{ Gender } & Male & 13 & 40.6 & 12 & 52.2 & \multirow{2}{*}{0.72} & \multirow{2}{*}{0.396} \\
\hline & Female & 19 & 59.4 & 11 & 47.8 & & \\
\hline
\end{tabular}

DM = diabetes mellitus; HTN = hypertension; IHD = ischemic heart disease. 
education, cases were higher in received years of education (8.6 \pm 3.95 year) compared to control group (5.3 \pm 2.87 years) but these difference was insignificant (Table $1, \mathrm{p}=0.093$ ).

Cases and control groups were matched for the occurrence of vascular risk illnesses as diabetes mellitus and hypertension (Table 2, $\mathrm{p}=0.097, \mathrm{p}=0.984$ respectively). In addition both groups were matched for the presence of other cardiovascular illness such as ischemic heart disease (Table $2 \mathrm{p}=0.039$ ).

The mean level of MMP3 in cases group was $\left(67.39 \times 10^{3} \mathrm{PC} / \mathrm{ml}\right)$ which was higher than control group $\left(61.65 \times 10^{3} \mathrm{PC} / \mathrm{ml}\right)$ though comparison between both groups was not significant (Table $\left.1, \mathrm{p}=0.519\right)$. On contrary the mean serum level of TIMP1 $\left(20.85 \times 10^{3} \mathrm{PC} / \mathrm{ml}\right)$ was lower than control group $\left(27.69 \times 10^{3} \mathrm{PC} / \mathrm{ml}\right)$, a difference which was significant between both groups (Table $1, \mathrm{p}=0.018$ ).

The cases group was further subdivided into 2 subgroups depending on NINDS-Airen criteria. Group 1 consisted of VDMI and group 2 consisted of VDSC. Serum levels of MMP3, TIMP1 were compared between both and between groups and the control group.

Mean serum MMP3 level was $\left(58.75 \times 10^{3} \mathrm{PC} / \mathrm{ml}, 73.33 \times 10^{3} \mathrm{PC} / \mathrm{ml}, 61.65 \times 10^{3} \mathrm{PC} / \mathrm{ml}\right)$ in VDMI subgroup, VDSC and control group respectively (Table 3 ).

There was no statistically significant difference in serum MMP3 level between dementia subgroups in comparison to each other (Table $3, \mathrm{p}=0.24$ ) or in comparison to control group.

Meanwhile mean serum level of TIMP1 was $\left(18.71 \times 10^{3} \mathrm{PC} / \mathrm{ml}, 22.53 \times 10^{3} \mathrm{PC} / \mathrm{ml}\right.$, and $\left.27.69 \times 10^{3} \mathrm{PC} / \mathrm{ml}\right)$ in VDMI subgroup, VDSC subgroup and control group respectively (Table 4).

Mean serum TIMP1 level in multi-infarct subgroup was statistically lower than control group (Table 4, $\mathrm{p}=$ 0.025). But there was no statistically significant difference between TIMP1 serum levels in subgroup comparison (Table 4, $\mathrm{p}=0.112$ ), or when comparing VDSC subgroup with control group (Table 4, $\mathrm{p}=0.161$ ).

\section{Discussion}

With the presence of many studies evaluated MMPs and their tissue inhibitors in Alzheimer s dementia patients, still few studies concentrated on MMPS evaluation in patients with vascular dementia. Many of that studies

Table 3. Comparison of serum level of MMP3 between vascular dementia subgroups and controls.

\begin{tabular}{cccc} 
& Mean MMP3 \pm SD \\
& & & T test \\
\cline { 3 - 3 } VDMI & $59.75 \pm 9.87$ & $\mathrm{t}$ & $\mathrm{p}$-value \\
\hline VDSC & $73.33 \pm 6.39$ & -1.2 & 0.24 \\
VDMI & $59.75 \pm 9.87$ & -0.163 & 0.871 \\
Control & $61.65 \pm 32.74$ & & 0.230 \\
VDSC & $73.33 \pm 6.39$ & 1.22 & 0 \\
control & $61.65 \pm 32.74$ & & \\
\hline
\end{tabular}

VDMI = Multi-infarct dementia; VDSC = Subcortical dementia; MMP3 = matrix metalloproteinase 3.

Table 4. Comparison of serum level of TIMP1 between vascular dementia subgroups and controls.

\begin{tabular}{|c|c|c|c|}
\hline & \multirow{2}{*}{$\begin{array}{l}\text { Mean TIMP } \pm \text { SD } \\
\times 10^{3} \text { picogram } / \mathrm{ml}\end{array}$} & \multicolumn{2}{|c|}{$\mathrm{T}$ test } \\
\hline & & $\mathrm{t}$ & p-value \\
\hline VDMI & 18.71 & \multirow{2}{*}{-1.638} & \multirow{2}{*}{0.112} \\
\hline VDSC & 22.53 & & \\
\hline VDMI & 18.71 & \multirow{2}{*}{-2.34} & \multirow{2}{*}{$0.025^{*}$} \\
\hline Control & 27.69 & & \\
\hline VDSC & 22.53 & \multirow{2}{*}{-1.428} & \multirow{2}{*}{0.161} \\
\hline control & 27.69 & & \\
\hline
\end{tabular}

\footnotetext{
${ }^{*}=$ significant $(\mathrm{p}<0.05)$; VDMI = Multi-infarct dementia; VDSC = Subcortical dementia; TIMP1 = tissue inhibitor metalloproteinase 1.
} 
measured brain tissue MMPs expression or cerebrospinal fluid level but few studies assessed MMPs and their inhibitors in serum.

The current study compared serum level of MMP3 and TIMP1 in vascular dementia subjects and cognitively intact control group.

The current study did not found a difference between serum level of MMP3 in both vascular dementia and control groups. This was the finding in subgroup analysis also. This finding did not indicate a possible role of MMP3 in the pathological process of vascular dementia in contrast to role MMP3 plays in Alzheimer's dementia. This can be partially explained by the fact that MMP3 has indirect important role in proteolytic activation of pro-MMPs [23] which may play a direct role in vascular dementia. Again some studies reported a role of MMP3 together with MMP2 and MMP9 in disrupting the Blood brain barrier following ischemia [24], this injurious effect may be detected within short period after ischemic stroke insult, and then disappeared.

While TIMP1 serum level was lower in vascular dementia cases compared to control subject's. Again with studding TIMP1 serum level in vascular dementia subgroups and compare it between subgroups, the same difference was evident with VDMI subgroup in comparison to control subjects. A finding that is in alignment with the finding of lower plasma levels of TIMP1 in vascular dementia patients when compared to control and Alzheimer's disease patients [25].

The current study finding support the the fact that TIMPs plays other roles than MMP dependent inhibition; TIMPs have cytokine like functions [26], proliferation and phenotypic differentiation of fibroblast [27].

This finding also coincides with new rationale of using MMP inhibitors for the treatment of stroke and vascular dementia [28].

\section{Conclusion}

The current study concluded that patients with VD particularly VDMI has lower serum level of TIMP1 as compared to control group. This finding highlights the presence of a role of TIMPI in the pathogenesis of vascular dementia. The significant role of metalloproteinases and their tissue inhibitors in vascular dementia is an area for further research and possible theraputic target in vascular dementia management.

\section{Acknowledgements}

I acknowledge the spiritual support I have from all my colleagues in Geriatric Department, Ain Shams University.

\section{Author Contributions}

Mohammed Zain Abdelwadoud Hussein study concept, study design, acquisition of subjects and data, interpretation of data, Statistical analysis, preparation and critical revision of the manuscript for important intellectual content and final approval of the manuscript.

\section{Sponsor's Role}

MMP3 and TIMP1 kits expenses covered by the author.

\section{Fund}

By Ain Shams University hospitals. There is no compliance with any research funding agency.

\section{Disclosure}

No potential conflicts of interest were disclosed.

\section{References}

[1] http://www.alz.org/dementia/vascular-dementia-symptoms.asp

[2] Pavlovic, A., Pavlovic, D., Aleksic, V. and Sternić, N. (2013) Vascular Dementia: Facts and Controversies. Srp Arch CelokLek, 141, 247-255. 
[3] Hebert, R. and Brayne, C. (1995) Epidemiology of Vascular Dementia. Neuroepidemiology, 14, 240. http://dx.doi.org/10.1159/000109800

[4] Wright, C.B. (2015) Etiology, Clinical Manifestations and Diagnosis of Vascular Dementia (on Line). www.uptodate.com/contents/etiology-clinical-manifestations-anddiagnosis-of-vasculardementia?Source=search_result \&search+vascular+dementia\&selected Title $=1 \sim 44$

[5] Gorelick, P.B., Scuteri, A., Black, S.E., Decarli, C., Greenberg, S.M., Iadecola, C., et al. (2011) Vascular Contributions to Cognitive Impairment and Dementia: A Statement for Healthcare Professionals from the American Heart Association/American Stroke Association. Stroke, 42, 2672-2713. http://dx.doi.org/10.1161/STR.0b013e3182299496

[6] Benisty, S. (2013) Current Concepts in Vascular Dementia. Geriatr Psychol Neuropsychiatr Vieil, 11, 171-180.

[7] Hachinski, V., Iadecola, C., Petersen, R.C., Breteler, M.M., Nyenhuis, D.L., Black, S.E., et al. (2006) National Institute of Neurological Disorders and Stroke-Canadian Stroke Network Vascular Cognitive Impairment Harmonization Standards. Stroke, 37, 2220-2241. http://dx.doi.org/10.1161/01.STR.0000237236.88823.47

[8] Caplan, L.R. (1995) Binswanger's Disease—Revisited. Neurology, 45, 626-633. http://dx.doi.org/10.1212/WNL.45.4.626

[9] Olszewski, J. (1962) Subcortical Arteriosclerotic Encephalopathy. Review of the Literature on the So-Called Binswanger's Disease and Presentation of Two Cases. World Neurology, 3, 359-375.

[10] Malemud, C.J. (2006) Matrix Metalloproteinases (MMPs) in Health and Disease: An Overview. Frontiers in Bioscience, 11, 1696-1701. (Review).

[11] Mroczko, B., Groblewska, M. and Barcikowska, M. (2013) The Role of Matrix Metalloproteinases and Tissue Inhibitors of Metalloproteinases in the Pathophysiology of Neurodegeneration: A Literature Study. Journal of Alzheimer's Disease, 37, 273-283.

[12] Rosenberg, G.A., Navratil, M., Barone, F. and Feuerstein, G. (1996) Proteolytic Cascade Enzymes Increase in Focal Cerebral Ischemia in Rat. Journal of Cerebral Blood Flow \& Metabolism, 55, 300-309

[13] Stomrud, E., Björkqvist, M., Janciauskiene, S., Minthon, L. and Hansson, O. (2010) Alterations of Matrix Metalloproteinases in the Healthy Elderly with Increased Risk of Prodromal Alzheimer's Disease. Alzheimer's Research \& Therapy, 2, 20. http://dx.doi.org/10.1186/alzrt44

[14] Helbecque, N., Cottel, D., Hermant, X. and Amouyel, P. (2007) Impact of the Matrix Metalloproteinase MMP-3 on Dementia. Neurobiology of Aging, 28, 1215-1220. http://dx.doi.org/10.1016/j.neurobiolaging.2006.05.030

[15] Saarela, M.S., Lehtimäki, T., Rinne, J.O., Hervonen, A., Jylhä, M., Röyttä, M., et al. (2004) Interaction between Matrix Metalloproteinase 3 and the Epsilon 4 Allele of Apolipoprotein E Increases the Risk of Alzheimer's Disease in Finns. Neuroscience Letters, 367, 336-339. http://dx.doi.org/10.1016/j.neulet.2004.06.027

[16] Maeda, A. and Sobel, R.A. (1996) Matrix Metalloproteinases in the Normal Human Central Nervous System, Microglial Nodules, and Multiple Sclerosis Lesions. Journal of Neuropathology and Experimental Neurology, 55, 300-309. http://dx.doi.org/10.1097/00005072-199603000-00005

[17] Clark, A.W., Krekoski, C.A., Bou, S.S., Chapman, K.R. and Edwards, D.R. (1997) Increased Gelatinase A (MMP-2) and Gelatinase B (MMP-9) Activities in Human Brain after Focal Ischemia. Neuroscience Letters, 238, 53-56. http://dx.doi.org/10.1016/S0304-3940(97)00859-8

[18] Anthony, D.C., Ferguson, B., Matyzak, M.K., Miller, K.M., Esiri, M.M. and Perry, V.H. (1997) Differential Matrix Metalloproteinase Expression in Cases of Multiple Sclerosis and Stroke. Neuropathology and Applied Neurobiology, 23, 406-415. http://dx.doi.org/10.1111/j.1365-2990.1997.tb01315.x

[19] Rosenberg, G.A., Sullivan, N. and Esiri, M.M. (2001) White Matter Damage Is Associated with Matrix Metalloproteinases in Vascular Dementia. Stroke, 32, 1162-1168. http://dx.doi.org/10.1161/01.STR.32.5.1162

[20] Roman, G.C., Tatemichi, T.K., Erkinjuntti, T., Cummings, J.L., Masdeu, J.C., Garcia, J.H., Amaducci, L., Orgogozo, J.M., Brun, A., Hofman, A., et al. (1993) Vascular Dementia: Diagnostic Criteria for Research Studies. Report of the NINDS-AIREN International Workshop. Neurology, 43, 250-260. http://dx.doi.org/10.1212/WNL.43.2.250

[21] Boster Biological Technology Co., Ltd. (2014) http://www.bosterbio.com/human-timp-1-picokine-elisa-kitek0520.html

[22] Boster Biological Technology Co., Ltd. (2014) http://www.bosterbio.com/human-mmp-3-picokine-elisa-kitek0461.html

[23] Chakraborti, S., Mandal, M., Das, S., Mandal, A. and Chakraborti, T. (2003) Regulation of Matrix Metalloproteinases: An Overview. Molecular and Cellular Biochemistry, 253, 269-285. http://dx.doi.org/10.1023/A:1026028303196

[24] Rosenberg, G.A., Cunningham, L.A., Wallace, J., Alexander, S., Estrada, E.Y., Grossetete, M., et al. (2001) Immunohistochemistry of Matrix Metalloproteinases in Reperfusion Injury to Rat Brain: Activation of MMP-9 Linked to Stromelysin-1 and Microglia in Cell Cultures. Brain Research, 893, 104-112. 
http://dx.doi.org/10.1016/S0006-8993(00)03294-7

[25] Lorenzl, S., Buerger, K., Hampel, H. and Beal, M.F. (2008) Profiles of Matrix Metalloproteinases and Their Inhibitors in Plasma of Patients with Dementia. International Psychogeriatrics, 20, 67-76. http://dx.doi.org/10.1017/s1041610207005790

[26] Stetler-Stevenson, W.G. (2008) The Tumor Microenvironment: Regulation by MMP-Independent Effects of Tissue Inhibitor of Metalloproteinases-2. Cancer and Metastasis Reviews, 27, 57-66. http://dx.doi.org/10.1007/s10555-007-9105-8

[27] Lovelock, J.D., Baker, A.H., Gao, F., Dong, J.F., Bergeron, A.L., McPheat, W., et al. (2005) Heterogeneous Effects of Tissue Inhibitors of Matrix Metalloproteinases on Cardiac Fibroblasts. AJP: Heart and Circulatory Physiology, 288, H461-H468. http://dx.doi.org/10.1152/ajpheart.00402.2004

[28] Roycik, M.D., Myers, J.S., Newcomer, R.G. and Sang, Q.X. (2013) Matrix Metalloproteinase Inhibition in Atherosclerosis and Stroke. Current Molecular Medicine, 13, 1299-1313. http://dx.doi.org/10.2174/15665240113139990067 